rooms contain souvenirs of former great Hungarian physicians. The so-called "pharmacy of Gömöry," of high artistic value, made in 1813 , is on exhibition, as well as some superb old apothecary jars from several Hungarian spas. The collection of several thousand pieces of medals, old surgical and medical instruments, and illustrations of folk medical cures must also be mentioned.
We hope that this museum, which is dedicated to the memory of the great Hungarian physician whom all the world has honoured, will attract a great number of visitors-We are, etc.,

K. FARKAS.

S. FERETE.

Swindon, Wilts. A. Palla.

power by emigration or to retain young doctors longer in the hospital service. There are no inducements to remain in hospital service apart from one's personal preference for this particulai type of medicine.

These criticisms should not detract from the motives behind the document, especially the advantages for the married houseman and the "permanent" registrar. Finally, although I criticize the B.M.A., the service given is undoubtedly good for a subsidized subscription fee of four guineas.-I am, etc., B. A. Wharton.

\title{
Hospital Junior Staff
}

SIR,-All junior hospital staff have received frequent communications (and rightly so) on the crisis in general practice-a matter which did not affect them directly. We have even had requests for financial support from the Birmingham Action Group. It is unfortunate, therefore, that the B.M.A. found it impossible to send a copy of the "Richmond Document" (a vital document to those who have chosen a hospital career) to each hospital doctor personally. The distribution to hospital secretaries, or alternatively the need for an individual request to the Association for a copy, is not satisfactory.

However, the document is very welcome and we are all indebted to the Central Consultants and Specialists Committee for its production, and particularly to Dr. HarveySmith for presenting evidence to them. The recommendations concerning residence charges, married quarters, and annual increments in pay are excellent in principle. No doubt they will be diluted considerably by the "Elephant."

Dr. Harvey Smith has asked for constructive criticisms:

Table I shows the salary one might expect on the present and proposed scale for either slow or rapid promotion up to the grade of senior registrar. The slow rate of promotion (such as seen in the major clinical specialties) shows a definite improvement in rates of pay, and indeed this was one of the aims of the proposed scales. However, even this increase is in fact $6 \%$ only. For the man enjoying a quicker promotion (e.g., as in many of the para-clinical specialties) the new rate shows no improvement- $0.5 \%$ increase only-and, in fact, for both rates of promotion the first-, second-, and third-year registrar will either have a fall in pay or no improvement. I presume this discrimination is unintentional. Nevertheless, a fall in rates of pay for our successors under whatever guise is unacceptable, and we should not accept the sop of allowing the at present first-year registrar to jump a year to $£ 1,595$ if the new scales are accepted. We have some responsibility for our successors.
Furthermore, although these scales would be subject to the 1966 pay review an excellent opportunity to point out the disparity in pay between the various branches of the profession has been missed. Table II shows the

TABLE II.-Pay Scales in the Three Clinical Branches of the N.H.S. An Efficiency Bar at (a) and a Severe Efficiency Bar at (b) are Present

\begin{tabular}{|c|c|c|c|}
\hline \multicolumn{2}{|c|}{$\begin{array}{l}\text { Hospital Service } \\
\text { Proposed Scales }\end{array}$} & \multirow{2}{*}{$\begin{array}{c}\text { General } \\
\text { Practice } \\
\text { from } \\
\text { B.M.尹. Adverts }\end{array}$} & \multirow{2}{*}{$\begin{array}{l}\text { Public Health } \\
\text { Asst. M.O. } \\
\text { Assuming } \\
\text { No Promotion }\end{array}$} \\
\hline Rapid & Slow & & \\
\hline $\begin{array}{r}1,000 \\
1,100 \\
\text { (a) } 1,425\end{array}$ & $\begin{array}{l}1,000 \\
1,100 \\
1,255\end{array}$ & $\begin{array}{l}2,000+\text { house } \\
\text { (a) } 3,000 \text { junior }\end{array}$ & $\begin{array}{l}\overline{1,515} \\
1,590\end{array}$ \\
\hline $\begin{array}{r}1,525 \\
1,595 \\
\text { (b) } 1,940 \\
2,050\end{array}$ & $\begin{array}{l}1,355 \\
1,425 \\
1,525 \\
1,595\end{array}$ & PARÍTY & $\begin{array}{l}1,665 \\
1,740 \\
1,815 \\
1,890\end{array}$ \\
\hline
\end{tabular}

rates of pay expected during the first seven years in the main branches of the N.H.S Are we, after only being less than seven years qualified, really worth only a half that of our general-practitioner colleagues of roughly the same age and experience? Or alternatively does general practice really need $100 \%$ inducement allowance-i.e., less than that offered to join the armed Forces? Salaries will to some extent depend on the labour available, but there is adequate evidence to show that the hospital service is as acutely short of young doctors as other branches of the N.H.S., especially as $40 \%$ of our members are foreign graduates.

I would conclude that:

(a) The increase for "slow promotion," although welcome, is small.

(b) Those enjoying a "rapid promotion" would have no increase and in some years would be worse off than under the present scales.

(c) First-, second-, and third-year registrars and first-year S.H.O.s would show no benefit and might well be worse off.

(d) The differential between pay scales of the hospital service and other branches of the N.H.S remain enormous without adequate professional or economic reasons for such a large difference.

(e) The changes proposed in the memorandum will do little to reduce the drain of medical man-

TABLE I.-Present and Proposed Salary Scales (in £) for Rapid or Slow Promotion

\begin{tabular}{|c|c|c|c|c|}
\hline & \multicolumn{2}{|c|}{ Slow Promotion } & \multicolumn{2}{|c|}{ Rapid Promotion } \\
\hline & Present & Proposed & Present & Proposed \\
\hline & $\begin{array}{r}810 \\
949 \\
1,195 \\
1,195 \\
1,425 \\
1,595 \\
1,595 \\
1,595\end{array}$ & $\begin{array}{l}1,000(+23 \%) \\
1,100(+17 \%) \\
1,255(+5 \%) \\
1,355(+13 \%) \\
1,425(-4 \%) \\
1,525(-4 \%) \\
1,595(-10 \%) \\
1,745(+10 \%)\end{array}$ & $\begin{array}{l}810 \\
1,195 \\
\\
1,425 \\
1,595 \\
1,595\end{array}$ & $\begin{array}{l}1,000(+23 \%) \\
1,100(-8 \%) \\
1,425 \quad- \\
1,525 \quad(-4 \%) \\
1,595\end{array}$ \\
\hline & \multicolumn{2}{|c|}{9 Years Qualified } & \multicolumn{2}{|c|}{5 Years Qualified } \\
\hline $\begin{array}{l}\text { Total income : } \\
\text { (a) including pre-reg. year } \\
\text { (b) excluding pre-reg. year }\end{array}$ & $\begin{array}{l}11,945 \\
11,130\end{array}$ & $\begin{array}{l}12,640(+6 \%) \\
11,640(+5 \%)\end{array}$ & $\begin{array}{l}6,620 \\
5,810\end{array}$ & $\begin{array}{ll}6,645 & (0.5 \%) \\
5,645 & (-3 \%)\end{array}$ \\
\hline
\end{tabular}

Sorrento Maternity Hospital,

Birmingham 15 .

SIR,-It was with interest that we read the recent memorandum "An Appraisal of the Hospital Service" (Supplement, 17 July, p. 70). Many of its proposals will be welcomed by junior hospital doctors. At a time when general-practitioner claims are very much to the fore it may be that the importance of this document will be overshadowed, and fear of this prompts us to write this letter.

A salary system based on yearly increments is highly desirable and long overdue. The scale proposed, however, is set surprisingly low. This is disappointing in a report which puts forward so many excellent principles regarding terms of service.

While those newly qualified would receive a much more reasonable salary, the rates proposed after the first two years are grossly inadequate. At one stage there would be little or no increase above the existing levels introduced in March 1963.

We can only hope that this fact will not be overlooked by those responsible for forwarding these new proposals to the review body, and that a higher scale will be substituted.-We are, etc.,

\section{J. A. Child.}

\section{Lewisham Hospital, S. GallanNaUgh. \\ London S.E.13.}

\section{Royal Commission on Medical Education}

SIR,-There can be no doubt that the setting up of a Royal Commission to survey and report on medical education will be approved by everyone. The present shortage of medical manpower is acute, and every branch of medical activity-hospitals, general practice, public health, the armed Forces, and so on-all seem to have deficiencies in their establishments, and, with increased commitments, these deficiencies look like growing rather than receding. The only branch which seems to have an adequacy of personnel (some would say too many) appears to be the teaching hospitals.

It must be said, therefore, that the constitution of the Royal Commission must give rise to some concern. Of the eminence and ability of the individual members of the Commission there cannot be the least shadow of doubt, and had the purpose of the Commission been to investigate the scientific development of medicine in this country it is doubtful whether a stronger team could have been gathered together. But, Sir, the question they are to investigate is medical 
education. A great majority of medical members on the Commission seem to come from the teaching hospitals, who have already fallen down on the job of providing enough and appropriate manpower to staff the National Health Service as we now find it.

There should surely be more generalpractitioner representation; there ought to be more representation of the peripheral hospitals (where authority forgets the great majority of the hospital work in this country is done); and there ought to be more representation of the public health services.

Lastly, since the development of the health services must be bound in with the development of the welfare services, ought there not to be some representation of local authorities who are responsible for the latter?

Is it too much to hope that, even at this late hour, the Commission should be strengthened by the addition of further members who are, maybe, less eminent, but who are certainly more concerned in those branches of medicine where the shortage is greatest.I am, etc.,

\section{$X$-ray Department, Newton Abbot Hospital,
Devon.}

A. Robinson Thomas.

\section{Medical Practice Freedom Fund}

SIR,-In response to our request for your assistance in publicizing the above fund you were kind enough to print a précis of our appeal circular in your journal (Supplement, 10 July, p. 27).

I have since received about 30 letters from all parts of the British Isles complaining that my address was not printed in full. Many have pointed out that they consider it the moral duty of those who do not resign to offer financial support to those who do ; and that they consider this matter merits the fullest publicity.

Can you assist again by printing this letter with my address below.-I am, etc.,

\section{A. J. WAINWRIGHT,}

28 Queslett Road, Birmingham Action Group Birmingham 22A.

\section{Report by the College of General Practitioners}

SIR,-There is no need for dismay at the revelations of the report of the College of General Practitioners. General-practitioner readers should turn to the current B.M.A. Members Handbook (1965), which states (p. 146) that visiting medical officers to establishments maintained by local authorities are remunerated at the rate of $£ 130$ a year for one hour a week spent at the establishment and $£ 235$ a year for two hours a week, with an addition of $£ 100$ for each hour over two. Hence a 40 -hour week would give $£ 4,035$ per annum plus mileage allowance. The fee for emergency visits between 9 a.m. and 8 p.m. is $£ 12 \mathrm{~s}$. $6 \mathrm{~d}$., and between 8 p.m. and 9 a.m. $£ 25$ s. 0d. Let our negotiators take note of these facts and not be intimidated any longer.

At the 1964 A.R.M. opposition to a salaried service for general practitioners was reaffirmed. If one values freedom from State domination one must concur with this view. However, if we are said to be losing public support one wonders if a small measure of nominal independence is worth while. The public should be told that the personal touch so essential for good medical practice can no longer be taken for granted and is being jeopardized for political vote-catching ends.

Can we afford a "free" Health Service? The answer could illustrate how other countries have better services where there is some degree of " self-help," even if it be but the profits from a lottery. The Health Service needs so much money for hospital improvements, hospital junior staff salary improvements, etc., quite apart from general practice improvements, that "self-help" and part payments will have to be introduced. I do not see any politician of any party with the courage to face the economic facts of life. It will be interesting to see what the politicians make of Mr. George Qvist's (B.M.F., 17 July, p. 174) proposal. What an inducement to improved standards of practice that would be. Alas, there is no hope of such a scheme being introduced unless we are resolute and united.

It is my belief that many patients are uncomfortable at the "something for nothing" attitude of the minority of their fellowpatients. Our quarrel must not be with the considerate majority of patients, who will, I am confident, accept our explanations if fairly presented.-I am, etc.,

Fareham, Hants.

\section{William J. O'ConNell.}

SIR,-It was with some incredulity that I read the report of the press on the findings of the College of General Practitioners referred to in your leader (24 July, p. 182). There may be some truth in the findings-the facts may apply to a medium-sized rural practice in summer, but not at any other time of the year, and certainly not to urban practice in the northern half of England at any time of the year.

This must surely be an open invitation to another four or five hundred young medical men to leave these shores over the next twelve months, since they are already condemned from within the ranks of their own profession as being inept and unable to cope with general practice. I do not see that any good can come of this report. It can cause incalculable harm.

Our negotiators have my sympathy in dealing with the Minister of Health, who must be rubbing his hands with glee over this unexpected windfall.-I am, etc.,

Gainsborough, Lincs.

\section{J. S. Topping.}

SIR,-In the B.M.F. (31 July, p. 298) you gave prominence to a letter from Dr. Logan Mitchell criticizing the College of General Practitioners' report on the "Present State and Future Needs" in which he "drew attention to one or two of its more glaring deficiencies," his first being that "no heed is given to the very real problem of emigration, nor is the word emigration used once in the whole report." The truth is that emigra- tion is discussed on pages 7 and 8 , where its extent is noted and reference is made to two papers on emigration by Abel-Smith and Gales and Seale.

As you, Sir, studied the report and wrote a two-column leading article about it, you must have known that Dr. Mitchell's statement was untrue. There has been a surfeit of ill-informed distortion of this very reasonable report elsewhere; in your columns let us have comment only from those who have read it with due care.-I am, etc.,

Hucclecote,
Gloucester.

Ivor Cookson.

SIR,-Dr. Annis Gillie and others in their letter (7 August, p. 358) state that the College of General Practitioners has no wish to take part in medico-political affairs; that it is concerned only with the "academic activity of investigating and improving standards of general practice." This letter seems to us to raise important issues concerning the respective roles of, and the relationship between, these two organizations, which require greater clarification than is attempted therein.

It is impossible to treat medical politics and the advancement of general practice as two watertight compartments, and to allocate the former to the B.M.A. and the latter to the College, even though much closer liaison may in future exist between these bodies. The recommendations of any report on medical practice conducted within the framework of a National Health Service are bound to have political and economic implications. The conclusion of the report "Present State and Future Needs" that the G.P. "must have adequate professional facilities, the tools to do the job, and full technical facilities, equipment, and ancillary staff with whom to work as members of a team " is no exception.

While the B.M.A. attempts to represent the interests of the medical profession as a whole, it shares with the College the common aim to improve general practice. As doctors who are jointly associates of the College and members of the B.M.A. we would ask of the B.M.A. that they accept the College as an authoritative advisory body on matters of general practice, and of the College that it should accept its share of political responsibility in negotiations with and through the B.M.A. for a new Charter for General Practice.-We are, etc.,

London N.W.1.

\section{Modell.}

R. WELLDON.

- SIR,-I was most interested to read the leading article "A Disappointing Report" (24 July, p. 182), which would seem to have been written with the intention of creating the impression that the report of the College of General Practitioners on "Present State and Future Needs of General Practice" is of doubtful value.

I suggest that your readers pay little attention to your editorial but form their own conclusions by reading the Report for themselves. They will then find that it is your editorial that is "misleading."-I am, etc.,

Stoke-on-Trent, Staffs.
H. W. K. ACHESON. 